\title{
Adapting Colonial Legacy to Modernism: A Focus on Rail Transport Development in Nigeria
}

\author{
Akwara, Azalahu Francis \\ Department of Political Science, Federal University Wukari,Taraba State, Nigeria. \\ Email: aakwara@yahoo.com; aquara23@nokiamali.com \\ Udaw, Joseph Effiong \\ Department of Political Science, Federal University Wukari,Taraba State, Nigeria \\ ettete2001@yahoo.com \\ Ezirim Gerald E. \\ Department of Political Science, University of Nigeria Nssuka. Enugu State, Nigeria \\ ekenezirim@yahoo.com
}

Doi:10.5901/mjss.2014.v5n6p465

\section{Abstract}

Colonial interest in Africa was hinged on a principle focused on amassing benefits to the imperial authority. Best efforts were, therefore, engaged to ensure maximum benefits possible. Agriculture and mineral products, required for sustained industrial development, were abundant in Africa. Harmonizing these identified elements, for efficient production, required an equally efficient mode of transport. Rail transport was, therefore, established and developed in Nigeria by the colonial British authority based on its strategic and capacity advantages. In this reasoning, a contemporary model of British railway was established and nurtured to serve colonial transport and logistics interests. Fifty-three years after Nigeria's independence, her railway system remains part of British (colonial) legacy in transport development history. This paper seeks to examine railway transport development in Nigeria. Both historical and empirical data are used in our analysis. And recommendations are made for sustainable development of the Nigeria railway system.

Keywords: externalities; competitiveness; efficiency; regularity; concession

\section{Introduction}

Up till date, the Nigerian Railway Corporation (NRC) remains a government-owned entity with the largest asset-base in terms of landed property. Buildings, machines and the gamut of railroad network are principally acquisitions of colonial administration. Due to continued neglect by successive post-colonial regimes, the once burgeoning enterprise plummeted to low ebb. The term 'moribund' is now commonly used to describe the NRC. Such description is informed by the level of operational dysfunction that has beset the Corporation.

Nigeria, as noted by Eleazu (1977), is a country of high human spatial mobility. Such population characteristic connotes high public transport demand. The need for an efficient means of mass carriage/haulage is, therefore, important. A resolution to restore the Nigerian railway system for effective and efficient performance requires more than lip-service and misleading publicity. Rather, pragmatic developmental policies and the will to transform this crucial infrastructure for common good are fundamental for such change. The restoration referred herein goes beyond mere continuance. But requires a shift from the traditional philosophy underlying railway establishment and operation in Nigeria to a people-oriented facility is preferred.

Transforming Nigeria's moribund railway to function contemporarily may seem formidable when we consider the enormity of fund requirement. What this paper seeks to address is the need for a shift in the Nigeria railway operational framework, from exploitative resource extraction corridor to a more broad-based mass transit facility. Given the level of rail service quality currently offered in Nigeria, there is the need to work toward meeting modern passenger and customers' expectations. Cost is identified as a considerable factor for meeting users' expectations. It is therefore sensible that provision of such infrastructure must be at minimum cost to the economy. To this end, a roadmap for 
adapting the colonial Nigerian railway infrastructure to modernity is proposed.

\section{Statement of the Problem}

Railway was established, by the British colonial authority, more than a decade ago. The management, infrastructure and operations of the Nigerian Railway were similar to the practice and structure in Britain. Rail transport development was almost at the same level in both British home-country and the Nigeria colony. The railway institution suffered casualty in greater part of post-colonial administrations, in Nigeria as a result of longstanding neglect. This stunted Nigerian Railway development. Now, government recognizes that a functional and efficient rail transport system is a critical factor in its national transformation pursuit.

Though efforts are on to revamp the Nigerian railway system, issues of uneven rail network-spread, minority groups' exclusion and lack of modern technology in rail transport management and operations remain unresolved. This paper is on the quest for how best Nigeria's colonial railway legacy can be adapted to modern management and operational practice, through efficient policy-design.

\section{Review of Relevant Literature}

So much has been written about the history of railway establishment in Nigeria. In fact, transport development history in Nigeria is not complete without mention of the railway. At the early stage of Nigeria's independence, in the 1960s, Robinson et al (1961) aptly expressed the role of railway as they noted that the overland freight movement was dominated by the railway to the extent that it controlled about one-third of the freight market share. The rail mode of transportation was recognized by Hogendorn (1970) as a significant producer-price incentive for sufficient farmers' engagement in the production of some cash crops such as cotton, cocoa and ground-nuts that were in high demand for British manufacturing industries. This recognition was premised on the fact that transport cost formed substantial part of the value of goods delivered. The motive of economic exploitation, as expressed by Jaekel (1997), is apparent in the corridors that they run through. Apart from the economic function of the railway, Elechi (1998) records that colonial government sustained administrative cohesion among the various units using the railway as an organization. Survey by the Nigerian Statistical Association (2000) showed that the railway began to lose its pre-eminent position in haulage to the seaports by the 1970s. This period also marked dominance of road transportation. By the end of the 1990s, the use of rail transport was reported to have fallen to insignificance. Scholars such as Oni and Okanlawon (2004) affirm the strategic importance of railway in Nigeria's urban and regional policy planning. They aver that transportation averagely accounts for $30 \%$ of the value of agricultural, manufactured and mining products. If transportation costs form a significant proportion of these goods, and, according to Filani (2003), road transport constitutes about $90 \%$ of goods movement; rail transport will significantly offer a relatively cheaper alternative. The overall impact of a shift to rail, as a dominant mode of transport, is likely to substantially reduce the final prices of most goods.

At the turn of events, the railway system, noted by Hogendorn (1970), to have daily ready haulage of 100 -ton groundnut (from Kano Station alone), in the early 1900s was strangely relegated to insignificance by the end of the century. This, certainly, points to the fact that the system basis must have been beset by insurmountable conditions. Neglect, arising from skewed public transport policy, fostered the growth of privately-owned long-distance transport services. The consequences of this policy inadequacy were put forward by observers such as Odeleye (2000), Aderamo (2013), and Patunola-Ajayi (nd). While Odeleye blamed exclusive government ownership of the Nigerian Railway for the neglect the Corporation suffers, Aderamo adduced reduced capacity and utility of the railway to same policy imbalance, Patunola blamed such policy for attendant problems (of increased fatal road accident rate and environmental damage) associated with unregulated private-sector dominated transport sector. However, they are unanimous in proffering private-sector participation in the ownership and management of railway transportation in Nigeria as a major panacea for rail transport challenges in Nigeria.

Due to the observed overwhelming transport demand pressure on automobile (road) vehicles in Nigeria, Oni (2004) recommended that the rail transport system is preferred no matter how limited it might be, in scope. Oni's recommendation is apt when one considers the sheer population (over 150 million) and their mobile nature. Again, the option of charging relatively low prices for rail services is preferred because it offers a motivating structure to a large mass of the population that are predominantly not high-earning. 


\section{Theoretical Framework}

This discourse is situated within the context of postcolonial theory, as espoused by Young (2001). He noted that the "tricontinental" awakening in Africa, Asia and Latin America brought about expression and struggles for freedom from imperial domination. The attention of this study is targeted at neo-colonialism and its agents (both local and international) -which are extension of political, economic and social exploitation in post-independent states. It is from these experiences that the postcolonial theory emerged.

The philosophy underlying postcolonial theory is not one of declaring war on the past but declaring war against the present realities which are consequences of the past. Postcolonial theory, therefore, arouses self-consciousness to the extent that there is a psychological rebirth between the oppressed (colonized) and the oppressor (colonizer). This revolutionary mindset calls for the need to address conditions that will engender liberty, equity and progress in the society.

In relation to this treatise on the Nigerian rail system, as a colonial (British) legacy in postcolonial time, we seek to redress the inordinate imperial objective of railway infrastructural provision. In doing this, we explore the potentials of a relatively equitable provision of rail services to emerging communities in order to meet their traffic-needs. The modernism factor falls in line with the underlying philosophy of post-colonialism that sets out to realign the status quo for equity and broad-based development. In other words, the proposed modern rail service, in Nigeria, is one with a wider service spectrum for wider clientele and value.

\section{Rail Transport Establishment in Nigeria}

Bulk long-distance haulage-need necessitated rail transport establishment in Nigeria. The need for the most effective and efficient means of evacuating agricultural and mineral produce from the hinterland to the seaports made rail transport preferred to other modes of transportation. Thus, the British imperial authority established the first railway corridor, in Nigeria, in 1898.

\subsection{Colonial railway stretch}

Most of what presently exists as railway network, in Nigeria, can be termed as colonial heritage. The railroad laid in 1898 stretched from Iddo to Otta, a distance of 34 kilometers. By 1930, most major towns such as Ilorin, Jebba, Minna, Gusau, Port-Harcourt, Enugu, Makurdi, and Zaria had been linked. An extension of the Borno rail linked Kuru to Maiduguri, in 1964. A total of 3,505 kilometers $(1,067 \mathrm{~mm}$ gauge) network of single-track railway constitutes the major functional stretch in the country. Specifically, the system comprises $2,792 \mathrm{~km}$ mainlines and $713 \mathrm{~km}$ branch lines. About $1,788 \mathrm{~km}$ $(51 \%)$ of this network is on 1,600 sharp curves between 4 and 10 degrees. This network mainly links the north-east and north-west extremes of Nigeria to coastal ports of Rivers and Lagos States, respectively.

\subsection{Purpose of establishment}

There is no need over-flogging the ease of material evacuation motive, of the British imperial authority, for establishing railway in Nigeria. Away from this popular notion, Jakpa (1981) remarked that administrative convenience was a fundamental consideration in the construction of the railway. It can, therefore, be surmised that railway establishment in Nigeria was inspired by the twin-need to generate revenue for sustaining the colonial bureaucracy and, also, to effectively carry out administrative functions.

\subsection{Operational model}

Rail transport operation, in Nigeria, is the prerogative of the federal government. An enabling 1955 Act of Parliament, as amended in the Laws of the Federation of Nigeria (1990), created the Nigerian Railway Corporation (NRC) as the sole managing and operating concern for railway operation in Nigeria. Before then, the management of railway system in Nigeria was the function of a department in the central government. By this pronouncement, sub-units to the central authority together with private enterprises are forbidden to carry in part (or full) any railway business as explicitly stated in the Act. The mandate of the NRC, as spelt out in the 1955 Act includes the following:

- Carriage of passengers and goods in a manner that will offer full value for money; 
- Meet the cost of operations;

- Improve market-share and quality of service;

- Ensure safety of operations and maximum efficiency; and

- Meet social responsibility in a manner that will meet the requirements of rail-users, trade, commerce, industry and the general public.

Although the establishment of the NRC was aimed at curtailing the rigid and bureaucratic influences of government, there was a financial consideration to this decision, also. It was reasoned that such measure would place the corporation in a position to operate as a semi-commercial enterprise. Regrettably, this measure did not immune the corporation completely from government interference. As aptly noted by Ayanwu (1995), matters regarding general policy, tariff-fixing and appointment of key officers were within the central government's purview. Thus, the very essence of 'handing over' the NRC to a management 'outside' government became an effort in futility since there was still government interference.

\section{Nigerian Railway and National Integration: Integration Capacity of the Railway}

The essence of good governance is, among others, to foster integration. On all fronts, (be it economic, social or political) the general well-being of the citizens must be desired. Provision of adequate infrastructure to meet any (or a combination) of these ends is, therefore, important. Commerce remains a melting pot for interaction among people within a society. Economic integration engenders the ambience required for nurturing stability in a federal system such as Nigeria.

Apart from opening up the hinterland, Nigeria's railways played a great role in providing the platform for foreign and domestic trade. In the course of people engaging in commercial activities, the country's socio-economic development can be enhanced. Unfortunately, such expectation is truncated by the limitations imposed by successive administrations' neglect of the rail transport sector.

With a population of over 120 million people, the potential for economic integration is inherent in Nigeria. Possibility of achieving significant economic integration can be through rapid urbanization and fluid mobility of both rural and urban populations. Yet, the non-existence of effective and efficient rail mass-transit infrastructure (resulting in the high cost of doing business) continues to serve as disincentive for investment. Olomola (2003) identified inadequate transport infrastructure services as the reason for the prevalent poverty across various Nigerian communities in both urban and rural areas. Interregional trade, industrial growth and commerce rely heavily on transportation. Considering the fact that the nature of agricultural produce in Nigeria is such that require bulk haulage over long distances, the rail transport sector would, therefore, offer cheaply effective means of carriage. The consequence of such infrastructural availability has the tendency to stimulate and strengthen economic integration among the various regional elements of the country.

\section{Challenges of Existing Railway in Nigeria}

What obtains as the existing railway, in Nigeria, is no different from that which was handed over from the British colonialists. Nigeria's rail transport development observers such as Oni and Okanlawon (2004) noted how deplorable this sector has become. Contemporary African countries' transport infrastructure bases are noted to fare better in terms of quality and service coverage. Of particular note, are the rural areas where agricultural practice is predominant.

Years of neglect, and the lack of government will, bear negatively on the capacity and utility of the Nigerian railway system. Consequently, traffic is lost to other modes especially road vehicles. The overall consequences are redundancy, reduced revenue base, workers' lay-off and further infrastructural deterioration. below:

The challenges of railway system, in Nigeria, range from structural to administrative. Some of these are stated,

a. Track structure: There are two prominent features of railway track. These are the rails and ballast (stones). Most of the existing functional railway network consists primarily of jointed rails of various weights $(30 \mathrm{~kg} / \mathrm{m}$ to $40 \mathrm{~kg} / \mathrm{m}$ ) with various carrying capacities of 12.5 tons to 20 tons, respectively. The ballast serves as cushion to the vibrating effect of the rolling stock on goods and passengers. These, not only limit the load they bear, but the comfort and convenience of passengers as well.

b. High operating costs: Effective train operations require equally effective communication system. The current epileptic public power supply, which the country is making effort to surmount, continues to hinder the supporting role of communication for effective and efficient train operation. The microwave telecommunicating facilities of the Nigerian Railway Corporation are supported by power-generating machines and solar panels, 
as alternative power sources. Such conditions lead to high operating costs which are at variance with the mandate establishing the Corporation

c. Sole government involvement: So long as politics influence growth and development, the influence of politicians on policies must not be overlooked. The overbearing influence of governments in rail development projects is as a result of the huge financial commitment involved. Hence, politicians are often interested in ensuring that such projects are brought to their constituencies -even if there is no real need for such. But if such demand were made to a private company, real need would prevail over political consideration.

Except remedial steps are taken, these challenges will continue to impair rail service delivery in Nigeria. Apart from the rail network construct, which is principally a linkage between the far northern regions to the coasts, exclusion of minority populace of the country is also a major challenge, especially the minority groups of the middle-belt and southeast.

\section{Previous Railway Resuscitation Efforts}

Before this time, there were some attempts to resuscitate the Nigerian railway system. The first of such effort began with the engagement of the Rail India Technical and Economic Services (RITES), by the government. RITES contract was for the period between 1978 and 1982. A second attempt, tagged 'Ogbemudia Revolution', was between 1989 and 1992. While the RITES project was to overhaul the rolling stock and manage the services of the NRC, the Ogbemudia Revolution brought a new dimension to local rail transport experience. However, the First National Rolling Plan (19901992) recognized that the benefits of RITES' efforts could not be sustained soon after they left.

The most significant effort at revamping the Nigerian railway system is the engagement of a Chinese company China Civil Engineering and Construction Corporation (CCECC) in 1995 for thirty-six months. The contract, worth about US $\$ 528,697,000$, required CCECC to fulfill the obligation of rail-track restoration which includes track surveys, track repair and re-alignment/reinforcement as well as reduction of sharp curves. Another major mandate in the contract was the provision of rolling stock. In this respect, CCECC supplied 50 locomotive, 150 coaches and 400 wagons. Watchers have reservations about the contract conclusion. While Odeleye (2000) noted that the project ended with marginal improvement in the service of Nigeria Railway Corporation (NRC), Adesanya (2002) observed that, by 1998, not all aspects of the mandate were fulfilled.

\section{Nigerian Railway and the Minority Populace}

The three hegemonic groups in Nigeria are: the Yoruba, Hausa-fulani and Ibo. Generically, they are referred to as 'wazobia'. Incidentally, these groups evidently benefit from the railway network put in place by the colonial authorities. The present two major functional rail corridors are the ones originating from Lagos to Nguru; and the other originating from Port-Harcourt to Maiduguri.

While attempting to define the 'minority' populace in Nigeria, Otite (1990) identified that this requires some classification as to the degree of 'minoritiness'. This is because there are many other minority groups that can further be stratified using numerical and political criteria. Interestingly, both criteria are of essence for the purpose of this citation. Therefore, numerical characteristic is also as important as the political. Table 1 shows Nigeria's minority groupings.

Table 1: Location of minority ethnic groups in Nigeria.

\begin{tabular}{|l|c|c|}
\hline \multicolumn{1}{|c|}{ States by zones } & 'Majority' Ethnic Group with some presence & Minority Ethnic Groups \\
\hline North West & & 54 \\
\hline Sokoto, Kebbi + Zamfara (Old Sokoto) & Hausa & 12 \\
\hline Katsina & Hausa & 1 \\
\hline Kano + Jigawa (old Kano) & Hausa & 9 \\
\hline Kaduna & Hausa & 32 \\
\hline North Central & & 123 \\
\hline Old Kwara ( + some parts of Kogi) & Yoruba, Hausa & 20 \\
\hline Old Niger & Hausa & 19 \\
\hline Old Benue (+ some parts of present Kogi) & Hausa & 12 \\
\hline Plateau + Nassarawa (Old Plateau) & Hausa & 72 \\
\hline North East & & 205 \\
\hline
\end{tabular}




\begin{tabular}{|l|c|c|}
\hline Borno + Yobe (old Borno) & - & 29 \\
\hline Adamawa + Taraba (old Gongola) & Hausa & 112 \\
\hline Bauchi + Gombe (old Bauchi) & Hausa & 64 \\
\hline South West & & 4 \\
\hline Oyo + Osun (Old Oyo) & Yoruba & 2 \\
\hline Ekiti + Ondo (Old Ondo) & Yoruba & - \\
\hline Ogun & Yoruba & 2 \\
\hline Lagos & Yoruba & 59 \\
\hline South South & & 13 \\
\hline Edo + Delta (old Bendel) & Igbo & 10 \\
\hline Rivers + Bayelsa (Old River) & Igbo & 7 \\
\hline Akwa Ibom & - & \\
\hline
\end{tabular}

Source: adapted from Otite, 1990

Within the prism of postcolonial theory, it is pertinent that we consider and address the imbalance created in the provision of a public transport utility such as the railway. Though democracy expresses the wish of majority, the interest of the minority must not be undermined. Extension or creation of new railroads that link most of the minority groups will, surely, give a sense of belonging to the affected groups and also affirm the philosophy of democracy.

In order to redress this rail network imbalance, the government is considering private partnership in the management and operation of the railway system, in Nigeria. To this end, the federal government of Nigeria plans to construct ten new rail-lines to cover other parts of the country that are not linked by rail. This includes a high-speed rail track from Lagos to Abuja. A list of other lines is as follows:

1. Ajaokuta - Eganyi - Lokoja - Abuja;

2. Ajaokuta- Otukpo;

3. Zaria - Kaura Namoda-IIlela - Birni Koni;

4. Benin - Sapele - Yenagoa - Uyo - Obudu Cattle Ranch;

5. Onitsha - Abakaliki - Enugu;

6. Port-Harcourt - Biu - Maiduguri;

7. Ikom - Katsina-Ala - Wukari - Jalingo - Ngala;

8. Lagos - Shagamu - ljebu-Ode - Ore - Benin; and

9. Benin - Agbor - Onitsha - Owerri - Aba - Abakaliki

In addition, a 25-30 year concessionary arrangement is planned for three separate concessionaires to run existing railroads in the western, central and eastern regions. Railway rehabilitation and upgrade is a major thrust of the national economic reform blueprint known as National Economic Empowerment and Development Strategies (NEEDS) (2004). The objective is to restore the relevance of the railways in the national transportation (bulk haulage and human) system. To substantiate this objective, Oni (2004) correlates the provision and development of efficient rail transport service with full utilization of a country's natural resources. He further asserts that the observed strain on automobile vehicles, and roads, is as a result of their being inundated by traffic demand, in Nigeria. The NEEDS programme is aligned with the country's transformation blueprint (Vision 20:2020 Document) which noted rail transportation as one of the key drivers of the economy.

\section{Minorities' Exclusion}

Indeed, when the above-mentioned newline projects in the railway sector are executed, they will not only result in a railway revolution but, also, enhance the socio-economic lives of the minority groups previously excluded. The 'federal character' principle, which seeks to check against the predominance of some groups over others, shall have assuaged the minorities' feeling of exclusion. Recognizing the need to, as much as possible, reflect national diversity is an effort at fulfilling the 'federal character' principle as enshrined in the Section 153 (1) of the 1999 Nigerian constitution.

\section{Global Rail Transportation Trend: Whither Nigeria?}

When we recall that as at the time of establishment of the Nigerian Railway Corporation, the system was modeled after the British Railway, we see that this institution was contemporarily modern. This supposes that operational and 
administrative practices in the Nigerian railway were similar to those in Britain. Then (in the late nineteenth and greater part of the twentieth century), the block telegraphic system characterized global train operations. Morse code communication was the trend. These practices were compliant with modernism in rail transportation. And, therefore, Nigeria was on the same level of rail transport development with other western countries.

In spite of Nigeria's century-old history of railway, Odeleye (2012) observed that the country's spate of development and growth is conspicuously slow when compared with its colleagues. Technologically and operationally her colleagues have advanced to attain an average train speed of $150 \mathrm{~km} / \mathrm{hr}$. Nigeria is still grappling with an average speed of $35 \mathrm{~km} / \mathrm{hr}$. While other railways have advanced to satellite control information systems, NRC still operates the key token instrument, semaphore signaling, and narrow gauge network to mention a few.

A comparative evaluation of railroad-spread between America and Nigeria is given by Collier (2011). Collier noted that while America is a huge landmass, with a relatively low population desity, yet it has one kilometer track for every 43 square kilometers of land. Nigeria, on the other hand, is reputed to have about one-fifth of the sub-Saharan African population and also one of its most densely populated countries yet, its rail-spread is one kilometer of rail for every 262 square kilometers. It is, therefore, not surprising that the volume of socio-economic activities is greater in America than Nigeria.

However, government has integrated railway development into its NEEDS programme as a way of reducing the developmental gap existing between Nigeria and her advanced contemporaries. One of such strategies is the need to develop and maintain adequate/appropriate infrastructure through significant private sector participation in rail service delivery. But the extent of such involvement is limited by the subsisting regulatory framework which grants government the monopoly of operation and management.

\section{Major Considerations in Establishing Rail Corridors}

The colonial administration did not just establish the Nigerian railway system simply for the purpose of accessing passage along its routes. Rather, they are motivated by deep economic and administrative considerations beneficial to the wellbeing of the home-government. In fact, the administrative factor can be tied to the necessity for social order conducive for carrying on their exploitation. So, it all boils down to economics. In a more populist manner, considerations in the establishment of a proposed rail corridor must take cognizance of its impact on the immediate and implicit costs to the public spectrum.

\section{Externalities}

In transportation, there is the concept of 'externalities'. These are costs created in the process of using vehicles in urban areas. These costs are borne by others, rather than the vehicle users. For instance, dwellers close to vehicle routes and facilities bear the costs of living in such proximity. Noise and air pollution have their adverse consequences on close dwellers to roads and their terminuses. Other issues are visual intrusion, fear and distraction to mention a few. The costs of ill-health, raising fences in cases of intrusion, beefing up security and so on, are not borne by the causal. Instead, other individuals unduly bear these consequences.

Therefore, there is need for operator charges, in respect of railway transport. These could be in form of taxes on fuel and lubricants, track sectional tolls and the likes. This is based on the argument that those who cause costs should be charged accordingly to augment allocations to social service provisions. Nigeria's transport policy (2003) considers that a well-designed user-tax system could become a technique of capacity rationing through price mechanism.

\section{Modal Competitiveness}

In Nigeria, automobile vehicles are mostly used by both private and public commuters. Therefore, any meaningful and effective public transport alternative must be such that reasonably competes with automobiles. The train has the virtue for bulk/simultaneous boarding (or loading) and disembarking (or unloading). Consequently, opportunity for bulk concession in tariff and fares is created. It is, therefore, important that rail corridors must be well managed and linked to potential commercial users. Thus, relative incentives to customers are more appealing in the rail mode. Modal competitiveness largely depends on efficiency parameters. 


\section{Efficiency Parameters}

The following factors are the basic efficiency parameters in rail transport service delivery:

Safety and security: The tendency for both passengers and goods to transit from origin to destination without damage, loss or wrong delivery requires a great amount of safety and security measures. Indeed, the rate of accident is dependent upon safety and security measures put in place.

Convenience: Accessibility, availability and the comfort of utilizing a train service define convenience in passenger train service. For goods, convenience includes the availability of handling equipment that can prevent spoilage.

Timeliness: This has to do with the appropriateness of the time which the train service is offered to the public. For instance, passenger trains scheduled for a time good enough to make a journey to and from work is said to be timely for workers. In the same vein, goods trains scheduled for times that enable both buyers and seller to transport their wares to and from market, in good time to connect with other means of transport, is also timely.

Regularity: This is determined by the level of consistency in train service availability. Regularity largely depends on the train service adherence to schedule. Regularity sustains passenger reliance and patronage to a transport system.

All these parameters must consist at every stage of the passenger/customer experience ranging from ticket purchase, pre-boarding/loading and transit, to check-out.

\section{Operational Framework}

Considering the operational framework to adopt, in establishing a rail corridor, is very important. Determining the operational framework involves task arrangement among units within the organization. Railway transport enterprise is capital intensive. It is, therefore, essential that care be taken in deciding which operational model/option to adopt. In this consideration, the dynamics of transport market is paramount. Operational model-choice must be such that maintains 'cost-balance' both to the operator(s), on the one hand, and passengers/customers, on the other hand. The World Bank (1999) stated the need for transport to be cost-effective and continuously responsive to market dynamics; that liberation arising from regulatory reform forces transport supplies to respond to users' needs at lower costs. The commercialization of public firms (such as the Nigerian railway) is necessary for economic and sustainability reasons. Private sector participation, therefore, becomes essential.

\section{Public-Private Participation (PPP)}

Although railways are permanent ways, their construction takes the process that requires an initial creation of a temporary way along a proposed rail corridor. The temporary way creates path for moving materials to and from site; the earth is propped to provide the bed for laying of tracks; and, at times, rocks have to be cut through to create the temporary path; then, the permanent way (rail track) is finally established. All of these involve huge human and material resources. Due to the enormous fund required in the provision of a railway system, convenient avenues for accessing such funds must be sourced. Public-Private partnership, in various forms and scales, is a key policy issue in financing all types of transport infrastructure.

In this situation, sourcing for a private commercial operator with core competence in rail infrastructure and operation management appears to be the most credible option. Private participation in rail transport service provision takes the form of a synergy with government. Contractual arrangements, in this instance, fall into three broad categories namely:

(a) Supply and Management Contracts;

(b) Lease; and

(c) Concessions

\subsection{Supply and management contracts:}

These include the private concessionaires' supply of non-core activities (such as catering, medical, cleaning to mention a few) of a railway organization on the one hand, and maintenance/operational management on the other hand.

\subsection{Lease:}

In this arrangement, the operator (leaseholder) is responsible for maintaining infrastructure and services. This model can 
be applied in combination with some other model such as 'Build-Rehabilitate-Operate-Transfer (BROT) which will require the private sector significant investment over a long period. Other models include 'Build-Operate-Transfer' (BOT) and 'Build-Own-Operate-Transfer' (BOOT), to mention a few.

Under the lease, the leaseholder retains revenue collected from customers/users of the facility and makes a specific lease payment to the contracting authority. Generally, the government maintains the responsibility for investment and thus bears investment risks. The operational risks are transferred to the operator. Fixed facilities and land are leased out for a longer period than for mobile assets.

\subsection{Concession:}

Here, the government grants specific rights to a private concern (concessionaire) to build and operate a facility for a period. The government retains ownership and plays the role of a regulator. There are two basic formats in concession. First, the concessionaire may pay to the government for granting concession rights. Second, the government may pay the concessionaire for attaining, maintaining and sustaining agreed targets (or quality). Either way, government is better off because expenditure is less than if government were to solely own and manage the facility. Another advantage of concession is that concession fees, paid by concessionaires, form part of the revenue base for attending to other pressing public needs by the government.

Public-private combination, according to Daramola (2003), has the three major benefits of: a) Shared cost, thus relieving the taxpayers and government of maintenance and expansion cost burden; b) Reduced cost, due to private sector relatively critical accountability and lower administrative cost burden than that of government; and c) Efficiency, which is a characteristic underlying philosophy of private enterprises. Fair profit, rather than profit maximization, is ensured through the instrumentality of regulation.

Effective and efficient rail transport service provision also involves the recognition of the role of the commercial users. They equally are a vital factor as the regulator and the rail operator. Collier (2011) identified Africa's need for private sector financed and managed rail network. He expressed concern, however, about a public regulator with discretionary powers to objectively cope with eventualities. This concern is founded on the peculiar governance environment reputed for corruption and other forms of public-office abuse, in Africa. Thus, there is a tendency for operators and users to suspect and mistrust such regulator even in an event of honest and objective policy reform or recommendation. As such, neither the operator nor its customers would be willing to risk investment under this condition.

So, a viable alternative to a domestic regulator with discretionary power is, according to Collier, an "international dispute board" whose members are accepted by the government, investors and customers. This is a standard means of international contract enforcement and indeed one commonly used both by foreign investors in China and Chinese investors in Africa.

For harmonious relationship among rail transport stakeholders, price factor must be well attended to maintain a mid-point that is considered valuable to both operator and rail service user. Fare is often the cause of contention between operators and user-groups in a railway-prevalent society such as Britain. The existence of a credible settlement board serves as mediating medium.

Almost for the past two decades, there seems to be a primary global trend in paradigm-shift in transport infrastructure and service provision. Government monopoly status is gradually transforming, and being limited, to infrastructure and service regulation/facilitation. The private sector usually plays the operators' role. It is time Nigeria joined the bandwagon.

\section{Adapting Nigeria's Colonial Railway to Modernism}

The current Nigerian Railway system is largely a British colonial construct. It was established to service British home government developmental pursuits occasioned by industrial revolution, at the time. Train services that are today enjoyed are incidental only in areas fortunate to be on the rail-route.

No doubt, the Nigerian railway system and its enormous asset-base remain part of British colonial legacy. But its continued neglect by successive post-colonial administrations has brought this once-burgeoning institution to a nearcomatose state. This misfortune is traceable to majorly, the 1955 Act establishing the Nigerian Railway Corporation (NRC) as it is known today. Of significant impact is the clause that restrains railway ownership and management to the federal government.

Expansion in the scope of government development responsibilities steadily relegated railway maintenance/management obligation. Consequently, infrastructure and operations became dysfunctional. The national 
transformation roadmap (of Goodluck Jonathan) recognizes railways as one of the critical infrastructure required for sustainable accelerated socio-economic growth. This focus, therefore, seeks avenues to redress anomalies in public rail transport service provision (through PPP) and ensure reduced cost burden on government for rail network expansion and maintenance.

Adapting Nigeria's colonial railway to modernism involves the provision of rail infrastructure and services to a wider public spectrum than maintaining the colonial legacy of self-serving objective. It behooves post-colonial Nigeria government to improve rail infrastructure for the benefit of both majority and minority interests. In such pursuits rests the post-colonial theory which essentially considers redressing the unfavourable consequences of the colonial past; and aim at attaining a desired social liberty and equity. Most of the challenges facing the current railway system in Nigeria are, in the first instance, political and economic. These include: sole government involvement, over-bearing government influence and high cost of operations. The associated social challenges (especially public office corruption and minority populace exclusion) are consequential on earlier-mentioned political and economic factors. It is important to state, also, that addressing these socio-political and economic challenges will significantly engender national integration.

The conspicuously slow rate of railway development and growth in Nigeria is worrisome. With a historical pedigree of over a century, the average Nigerian train speed is 35kilometer per hour when her contemporaries' average speed is 150 kilometer per hour. Adapting existing infrastructure and operations to modernity requires radical approach involving the establishment of corridors with modal competitive capability in terms of efficiency.

From the foregoing, it is arguable that inadequate rail transport facilities and services have imposed constraint on the mobility and accessibility of people (especially the minority groups of the Middle Belt and South-Eastern Nigeria) to facilities such as markets, hospitals and good highway link. These have grave implication on deepening poverty levels in the areas. Thus, the plan to liberalize the rail transport sector will go a long way in achieving rail network widespread and enhance commerce and integration.

It is obvious that railway occupies a pre-eminent position within the context of transport coordination. It is for this reason that the Nigerian government has embarked on a 25 -year strategic railway-plan aimed at providing a robust railway system that will serve the socio-economic needs and interests of the country. But government must note that its bureaucratic interference in railway administration retards the progress of railway development in Nigeria and, therefore, should streamline its role strictly to that of a regulator.

\section{Summary and Conclusion}

From the foregoing essay, these observations are made:

1. Failures in the earlier attempts to resuscitate railway system in Nigeria were not essentially as a result of funds paucity. Rather, these failures arise as a result of faulty policy-design and government's lack of will;

2. The long period of railway neglect in Nigeria and eventual dysfunction has substantially aided the diversion of passenger and goods traffic to the highways. Consequently, such trend overwhelmed the roads; resulting in high road accident and fatality rates.

3. Major minority groups are excluded in the colonial rail network. As such, these areas are deprived of the commercial benefits that result from the provision of railway facility in some other communities.

So, it can be seen how poor transport policy-design has led to the sector's uneven development. Even the seemed unduly advantaged road sub-sector is strained by overwhelming traffic-offer. Thus, road quality sustenance is continuously hindered by the need for frequent maintenance. Furthermore, the faulty transport policy-design (and, in effect, the railway network design) accounts for the deprivation and underdevelopment that some minority group areas suffer. It must be pointed out that a major policy issue is the 1955 Act relating to railway operation and management.

\section{Recommendations}

In the light of these observations, the following recommendations are hereby submitted:

1. A review of the Railway 1955 Act, to allow for liberal participation of private and other government units with core competence in railway operations and management. In other words, the existing government monopoly must be broken to mitigate the incidences of bureaucratic interference.

2. An international mediation board, acceptable to the regulators and operators, must be established and involved in all rail contracts. This is to moderate and resolve contentious issues -especially those relating to pricing. 
3. Emphasis must be laid on coordinated Corporate Social Responsibilities (CSR) by the operators. Apart from keeping up with corporate ethics, such gestures are usually appreciated by host communities as make-up for externalities borne by them.

4. Government must exhibit strong determination and will to harness rail transport infrastructure and resources for an integrated transport system. Developed transport systems, in some advanced countries, are characterized by intermodalism. Nigeria must take advantage of her sheer population size by using intermodalism to stimulate and build a strong, sound and viable economic environment.

It is believed that the obligation rests on Nigerian government to amend and evolve railway transport policies that are in tune with modern realities. Concern must not necessarily be to catch up with contemporary British level of rail transport development. Rather, this paper subscribes to the government of Nigeria creating policies (and taking actions) to reduce the gulf in her railway development lagging.

\section{References}

Aderamo, A. J. (2013); "Transport Infrastructure and the Nigerian Environment: A Review"; International Review of Business and Social Sciences, 1 (6) 98-105

Adesanya, A. (2002); "Declining Fortunes of Rail Transport in Nigeria: Response and Direction of Policy" NISER Monograph Series No.8, NISER, Ibadan.

Adesanya, A. (2010); "Bringing the Nigerian Railways Back on Track: Challenges and Options" NISER Seminar Series, Lagos.

Ayanwu, J.C. (1995); "Structure of the Nigerian Economy (2) quoted in, European Commission (2008); Modern Rail Modern Europe: Towards an Integrated European Railway Area; Shutterstock, Luxembourg. publications.europa.eu

Collier, P. (2011); "Building an African Infrastructure: Building Railways in Africa"; Finance and Development, vol. 48 (4) 18-21

Daramola, A. Y. (2003); "Innovative Options for Financing Transport Infrastructure in Nigeria", in, NISEREEL, The Magazine of the Nigerian Institute of Social and Economic Research, Nos. 4 \& 5, Ibadan.

Eleazu, U. (1977); Federalism and Nation-Building: The Nigerian Experience, 1954-1964; Denvon: Arthur H. Stockwell Limited,

Elechi, S. I. O. (1998); "Rail Transport in Nigeria: Problems and Prospect"; in, Eniola, J. O.; Transport: A Developmental Catalyst, Lagos: Tranec Nigeria Limited,

Filani, M. (2003); "Advancing the Cause of Private Participation in the Road Transport Sub-sector in Nigeria"; a paper delivered at the 10th anniversary celebration of the Associated Bus Company (ABC) Ltd., at Ikeja.

First National Rolling Plan, 1990-92, Vol.1:162

Hogendorn, J.S. (1970); "Economic Initiative and African Cash Farming"; in, Gann, L.H. and Duignan, P. (eds.); Colonialism in Africa 1870-1960 (vol. 4); London: Cambridge University Press,

Hogendorn, J.S. (1970); "The Origins of Groundnut Trade in Northern Nigeria"; in, Eicher, C.K. and Liedholm, C. (eds); Growth and Development of Nigerian Economy. EastLansing Michigan State University Press,

Jaekel, F.(1997); History of the Nigerian Railway, (Vol.2); Ibadan: Spectrum Books Limited,

Jakpa, P. E. (1981); "Nigerian Railways in the 1980s"; in. Onakomaiya, S. O. and Ekanem, N. F.,(eds.) Transport in Nigerian National Development. Ibadan:NISER

Laws of the Federation of Nigeria (1990 revised edition); Chapter 323, Act No.20, vol. 18, pp. 11950 - 12006

National Transport Policy in Nigeria National Development (Proceedings of a National Conference, NISER, Ibadan. Pp 67-89

NEEDS Document (2004); National Economic Empowerment and Development Strategy; National Planning Commission, Abuja.

Nigerian Statistical Association (2000); "Transport Statistics and National Development"; Conference Proceedings, Lagos.

Odeleye, J. A. (2012); "Politics of Rail Transport Development in Developing Countries: Case of Nigeria"; Journal of Civil Engineering and Architecture, USA, vol. 6(12), pp 1695-1702

Odeleye, J.A. (2000); "Public-Private Participation to Rescue Railway Development in Nigeria"; Japan Railway and Transport Review 23, 42-49.

Olomola, A. S. (2003); "Understanding Poverty in Nigeria: Highlights from NISER Review of Nigerian Development"; NISREEL, (The Magazine of the Nigerian Institute of Social and Economic Research Ibadan, Nos. 4 and 5 ,

Oni, S. I. (2004): "Development of Urban Transportation"; in, Perspectives on Urban Transportation in Nigeria (ed) by Vandu-Chikolo et al; Zaria: Nigerian Institute of Transport Technology (NIIT). Pp. 53-69.

Oni, S.I. and Okanlawon, K. R (2004); Nigeria's Transport Infrastructural Development: An Integral Part of the National Economic Empowerment and Development Strategy (NEEDS). Lagos: Department of Geography, University of Lagos, Akoka-Lagos.

Otite, O. (1990); Ethnic Pluralism and Ethnicity in Nigeria. Ibadan: Shaneson

Patunola-Ajayi, B. J. (nd); "Infrastructure Development and Economic Empowerment in Nigeria"; Being a conference paper at the Nigerian Institution of Estate Surveyors and Valuers;niesv.org.ng/wp-content/uploads/2013/.../Presentation-for-conference. Retrieved electronically on September 21, 2013.

Robinson, H., Smith, S. R., and Clare, K. G. (1961); The Economic Coordination of Transport Development in Nigeria. Carlifornia: Stanford Research Institute.

The World Bank (1999); Sustainable Transport, Priorities for Policy Reform. Washington D.C.: The World Bank,

Young, R. J. C (2001); Post-Colonialism: An Historical Introduction. London Blackwell. 
